\title{
Maternal Thyroid-Adrenal Dysfunction and Fetal-Neonatal Depression
}

\author{
Ahmed R.G* \\ Division of Anatomy and Embryology, Zoology Department, Faculty of Science, Beni-Suef University, Beni- \\ Suef, Egypt \\ *Corresponding Author: Ahmed R.G., Division of Anatomy and Embryology, Zoology Department, \\ Faculty of Science, Beni-Suef University, Beni-Suef, Egypt, Email: ahmedragab08@gmail.com
}

\section{COMMENTARY}

The coordination between the thyroid hormones (THs) (El-bakry et al., 2010; Ahmed, 2011, 2012a,b, 2013, 2014, 2015a-c, 2016a-d, 2017av, 2018a-s; Ahmed and Ahmed, 2012; Ahmed et al., 2008; 2010; 2012; 2013a,b, 2014, 2015a,b, 2018a,b; Ahmed and Incerpi, 2013; Van Herck et al., 2013; Ahmed and El-Gareib, 2014, Incerpi et al., 2014; Candelotti et al., 2015; De Vito et al., 2015; El-Ghareeb et al., 2016; Ahmed and El-Gareib, 2017; Endendijk et al., 2017; Gigena et al., 2017) and glucocorticoids (Ahmed, 2016b) is necessary for the maternalfetal communications, the intrauterine/ extrauterine homeostasis, and the initiation of parturition (Fisher , 1997; Mesiano and Jaffe, 1997; Ng, 2000; Ishimoto and Jaffe, 2011; Hillman et al., 2012; Chung, 2014). After labor, the fetal hormones of thyroid [thyroxine (T4) and triiodothyronine (T3)] and adrenal cortex (cortisol) quickly respond to avoid the hypocalcemia, hypoglycemia, and hypothermia due to the absence of the placental supply of energy and nutrients (Chung, 2014). The cortisol surge (increase the level of cortisol with the progress of the gestation) augments the conversion of T4 to T3 (Kronenberg et al., 2008).

On the other hand, the endocrine anomalies may increase the risk of morbidity and several developmental disorders (Watterberg, 2004; La Gamma et al., 2009). Dysfunction in the hypothalamus-pituitary-thyroid axis (HPTA) and the hypothalamic-pituitary-adrenal axis (HPAA) can cause the major depressive disorders (Jackson, 1998; Kirkegaard and Faber, 1998; Brouwer et al., 2005). In depression, the dysfunction in HPTA can be attributed to (1) deficiency in the concentrations of serotonin and/or norepinephrine (Kirkegaard and Faber, 1998); and (2) elevation in the level of cortisol (hypercortisolism) (Brouwer et al., 2005). In major depression, the stimulation of HPAA can be explained by (1) the glucocorticoid resistance (Brouwer et al., 2005); and (2) hypothalamic overdrive of corticotrophin-releasing hormone (CRH) (Holsboer and Barden, 1996). In disagreement with these data, some authors did not find association between the major depression and the disorders in the HPTA (Haggerty et al., 1987; Sullivan et al., 1997; Engum et al., 2002) or HPAA (Rubin et al., 1987; Oldehinkel et al., 2001; Young et al., 2001). The inconsistency in these associations may depend on the status of the patient (in/outpatient), unipolar/bipolar depression, sex type, antidepressant medications (short- or longterm) (Dilsaver and Greden, 1985; Kraus et al., 1987; Baumgartner et al., 1988; Barden et al., 1995; McCowen et al., 1997; Bauer et al., 2002; Schule et al., 2003; Brouwer et al., 2005), and small sample sizes (Kirkegaard et al., 1990; Michelson et al., 1996; Coiro et al., 1998; Young et al., 2001; Brouwer et al., 2005). On the basis of these data, it can be decided that any disorders in the communications between the HPTA and HPAA during the gestation may cause a depression in both mothers and fetuses/neonates. Thus, additional studies are necessary to understand the potential associations between the fetal/perinatal adrenalthyroid disorders and depression. Future examinations are wanted to discover whether the effect of maternal thyroid hormone replacement therapy on the developmental 
thyroid-adrenal axis play a role in modifying the signaling pathways to enhance the atypical, melancholic or severe depression during the perinatal period.

\section{REFERENCES}

[1] Ahmed, O.M., Abd El-Tawab, S.M., Ahmed, R.G., 2010. Effects of experimentally induced maternal hypothyroidism and hyperthyroidism on the development of rat offspring: I- The development of the thyroid hormonesneurotransmitters and adenosinergic system interactions. Int. J. Dev. Neurosci. 28, 437-454.

[2] Ahmed, O.M., Ahmed, R.G., 2012. Hypothyroidism. In A New Look At Hypothyroidism. Dr. D. Springer (Ed.), ISBN: 978-953-51-0020-1), In Tech Open Access Publisher, Chapter 1, pp. 1-20.

[3] Ahmed, O.M., Ahmed, R.G., El-Gareib, A.W., El-Bakry, A.M., Abd El-Tawab, S.M., 2012. Effects of experimentally induced maternal hypothyroidism and hyperthyroidism on the development of rat offspring: II-The developmental pattern of neurons in relation to oxidative stress and antioxidant defense system. Int. J. Dev. Neurosci. 30, 517-537.

[4] Ahmed, O.M., El-Gareib, A.W., El-bakry, A.M., Abd El-Tawab, S.M., Ahmed, R.G., 2008. Thyroid hormones states and brain development interactions. Int. J. Dev. Neurosci. 26(2), 147-209. Review.

[5] Ahmed, R.G., 2011. Perinatal 2, 3, 7, 8tetrachlorodibenzo-p-dioxin exposure alters developmental neuroendocrine system. Food Chem. Toxicology, 49, 1276-1284.

[6] Ahmed, R.G., 2012a. Maternal-newborn thyroid dysfunction. In the Developmental Neuroendocrinology, pp. 1-369. Ed R.G. Ahmed. Germany: LAP LAMBERT Academic Publishing GmbH \& Co KG.

[7] Ahmed, R.G., 2012b. Maternal-fetal thyroid interactions, Thyroid Hormone, Dr. N.K. Agrawal (Ed.), ISBN: 978-953-51-0678-4, In Tech Open Access Publisher, Chapter 5, pp. 125-156.

[8] Ahmed, R.G., 2013. Early weaning PCB 95 exposure alters the neonatal endocrine system: thyroid adipokine dysfunction. J. Endocrinol. 219 (3), 205-215.

[9] Ahmed, R.G., 2014. Editorial: Do PCBs modify the thyroid-adipokine axis during development? Annals Thyroid Res. 1(1), 11-12.

[10] Ahmed, R.G., 2015a. Chapter 1: Hypothyroidism and brain development. In advances in hypothyroidism treatment. Avid Science Borsigstr. 9, 10115 Berlin, Berlin,
Germany. Avid Science Publications level 6, Melange Towers, Wing a, Hitec City, Hyderabad, Telangana, India. pp. 1-40.

[11] Ahmed, R.G., 2015b. Hypothyroidism and brain developmental players. Thyroid Research J. 8(2), 1-12.

[12] Ahmed, R.G., 2015c. Editorials and Commentary: Maternofetal thyroid action and brain development. J. of Advances in Biology; 7(1), 1207-1213.

[13] Ahmed, R.G., 2016a. Gestational dexamethasone alters fetal neuroendocrine axis. Toxicology Letters, 258, 46-54.

[14] Ahmed, R.G., 2016b. Neonatal polychlorinated biphenyls-induced endocrine dysfunction. Ann. Thyroid. Res. 2 (1), 34-35.

[15] Ahmed, R.G., 2016c. Maternal iodine deficiency and brain disorders. Endocrinol. Metab. Syndr. 5, 223. http://dx.doi.org/10.41 72/2161-1017.1000223.

[16] Ahmed, R.G., 2016d. Maternal bisphenol A alters fetal endocrine system: Thyroid adipokine dysfunction. Food Chem. Toxicology, 95, 168-174.

[17] Ahmed, R.G., 2017a. Developmental thyroid diseases and GABAergic dysfunction. EC Neurology 8.1, 02-04.

[18] Ahmed, R.G., 2017b. Hyperthyroidism and developmental dysfunction. Arch Med. 9, 4.

[19] Ahmed, R.G., 2017c. Anti-thyroid drugs may be at higher risk for perinatal thyroid disease. EC Pharmacology and Toxicology 4.4, 140142.

[20] Ahmed, R.G., 2017d. Perinatal hypothyroidism and cytoskeleton dysfunction. Endocrinol Metab Syndr 6, 271. doi:10.4172/21611017.1000271

[21] Ahmed, R.G., 2017e. Developmental thyroid diseases and monoaminergic dysfunction. Advances in Applied Science Research 8(3), 01-10.

[22] Ahmed, R.G., 2017f. Hypothyroidism and brain development. J. Anim Res Nutr. 2(2), 13.

[23] Ahmed, R.G., 2017g. Antiepileptic drugs and developmental neuroendocrine dysfunction: Every why has A Wherefore. Arch Med 9(6), 2.

[24] Ahmed, R.G., 2017h. Gestational prooxidantantioxidant imbalance may be at higher risk for postpartum thyroid disease. Endocrinol Metab Syndr 6, 279. doi:10.4172/2161-1017.1000279.

[25] Ahmed, R.G., 2017i. Synergistic actions of thyroid-adipokines axis during development. Endocrinol Metab Syndr 6, 280. doi:10.4172/ 2161-1017.1000280. 
[26] Ahmed, R.G., 2017j. Thyroid-insulin dysfunction during development. International Journal of Research Studies in Zoology 3(4), 73-75. DOI: http://dx.doi.org/10.20431/2454941X.0304010.

[27] Ahmed, R.G., 2017k. Developmental thyroid diseases and cholinergic imbalance. International Journal of Research Studies in Zoology 3(4), 70-72. DOI: http://dx.doi.org/ 10.20431/2454-941X.0304009.

[28] Ahmed, R.G., 20171. Thyroid diseases and developmental adenosinergic imbalance. Int $\mathbf{J}$ Clin Endocrinol 1(2), 053-055.

[29] Ahmed, R.G., 2017m. Maternal anticancer drugs and fetal neuroendocrine dysfunction in experimental animals. Endocrinol Metab Syndr 6, 281. doi:10.4172/2161-1017.1000281.

[30] Ahmed, R.G., 2017n. Letter: Gestational dexamethasone may be at higher risk for thyroid disease developing peripartum. Open Journal Of Biomedical \& Life Sciences (Ojbili) 3(2), 01-06.

[31] Ahmed, R.G., 2017o. Deiodinases and developmental hypothyroidism. EC Nutrition $11.5,183-185$.

[32] Ahmed, R.G., 2017p. Maternofetal thyroid hormones and risk of diabetes. Int. J. of Res. Studies in Medical and Health Sciences 2(10), 18-21.

[33] Ahmed, R.G., 2017r. Association between hypothyroidism and renal dysfunctions. International Journal of Research Studies in Medical and Health Sciences 2(11), 1-4.

[34] Ahmed, R.G., 2017s. Maternal hypothyroidism and lung dysfunction. International Journal of Research Studies in Medical and Health Sciences 2(11), 8-11.

[35] Ahmed, R.G., 2017t. Endocrine disruptors; possible mechanisms for inducing developmental disorders. International journal of basic science in medicine (IJBSM) 2(4), 157-160.

[36] Ahmed, R.G., 2017u. Maternal thyroid hormones trajectories and neonatal behavioral disorders. ARC Journal of Diabetes and Endocrinology 3(2), 18-21.

[37] Ahmed, R.G., 2017v. Maternal thyroid dysfunction and neonatal cardiac disorders. Insights Biol Med. 1, 092-096.

[38] Ahmed, R.G., 2018a. Maternal hypothyroidism and neonatal testicular dysfunction. International Journal of Research Studies in Medical and Health Sciences 3(1), 8-12.

[39] Ahmed, R.G., 2018b. Maternal hypothyroidism and neonatal depression: Current perspective. International Journal of Research Studies in
Zoology 4(1), 6-10. DOI: http://dx.doi.org/ 10.20431/2454-941X.0401002.

[40] Ahmed, R.G., 2018c. Non-genomic actions of thyroid hormones during development. App Clin Pharmacol Toxicol: ACPT-108. DOI: 10.29011/ACPT-109. 100008.

[41] Ahmed, R.G., 2018d. Maternal thyroid function and placental hemodynamics. ARC Journal of Animal and Veterinary Sciences 4(1), 9-13. DOI: http://dx.doi.org/10.20431/2455-2518. 04 01002.

[42] Ahmed, R.G., 2018e. Interactions between thyroid and growth factors during development. ARC Journal of Diabetes and Endocrinology 4(1), 1-4. DOI: http://dx.doi.org/ 10.20431/ 2455-5983.0401001.

[43] Ahmed, R.G., 2018f. Maternal thyroid hormones and neonatal appetite. ARC Journal of Nutrition and Growth 4(1), 18-22. DOI: http://dx.doi.org/10.20431/2455-2550.0401005.

[44] Ahmed, R.G., 2018g. Genomic actions of thyroid hormones during development. ARC Journal of Diabetes and Endocrinology 4(1), 58. DOI: http://dx.doi.org/10.20431/2455-5983. 0401002.

[45] Ahmed, R.G., 2018h. Dysfunction of maternal thyroid hormones and psychiatric symptoms. American Research Journal of Endocrinology. 2(1), 1-6.

[46] Ahmed, R.G., 2018i. Is there a connection between maternal hypothyroidism and developing autism spectrum disorders? ARC Journal of Neuroscience 3(1), 5-8. DOI: http://dx.doi.org/10.20431/2456057X.0301002.

[47] Ahmed, R.G., 2018j. Maternal thyroid dysfunctions and neonatal bone maldevelopment. American Research Journal of Endocrinology (in press) Xx-Xxx.

[48] Ahmed, R.G., 2018k. Maternal thyroid disorders and risk of neonatal seizure: Current perspective. ARC Journal of Neuroscience 3(1), 21-25. DOI: http://dx.doi.org/10.20431/2456057X.0301004

[49] Ahmed, R.G., 20181. Gestational dioxin acts as developing neuroendocrine-disruptor. EC Pharmacology and Toxicology 6.3, 96-100.

[50] Ahmed, R.G., 2018m. Maternal thyroid dysfunction and risk of neonatal stroke. ARC Journal of Animal and Veterinary Sciences 4(1), 22-26. DOI: http://dx.doi.org/ 10.20431/ 2455-2518.0401004

[51] Ahmed, R.G., 2018n. Maternal thyroid disorders and developing skin dysfunctions. 
ARC Journal of Dermatology 3(1), 13-17. DOI: http://dx.doi.org/10.20431/2456-0022.0301005

[52] Ahmed, R.G., 2018o. Maternal hypothyroidism-milk ejections: What is the link? ARC Journal of Nutrition and Growth 4(1), 29-33. DOI: http://dx.doi.org/10.20431/ 2455-2550.0401007

[53] Ahmed, R.G., 2018p. Does maternal antepartum hypothyroidism cause fetal and neonatal hyponatremia? ARC Journal of Diabetes and Endocrinology 4(1), xx-xxx. DOI: http://dx.doi.org/10.20431/2455-5983.0401004

[54] Ahmed, R.G., 2018q. Maternal hypothyroidism and rheumatoid arthritis. International Journal of Research Studies in Medical and Health Sciences Volume 3(2), 1-5.

[55] Ahmed, R.G., 2018r. Developmental thyroid and skeletal muscle dysfunction. ARC Journal of Diabetes and Endocrinology 4(1), xx-xxx. DOI: http://dx.doi.org/10.20431/2455-5983.04 01003.

[56] Ahmed, R.G., 2018s. Hyperthyroidism and renal disorders. ARC Journal of Animal and Veterinary Sciences 4(2), XX-XX. DOI: http://dx.doi.org/10.20431/2455-2518.0402001

[57] Ahmed, R.G., Abdel-Latif, M., Ahmed F., 2015b. Protective effects of GM-CSF in experimental neonatal hypothyroidism. International Immunopharmacology 29, 538543.

[58] Ahmed, R.G., Abdel-Latif, M., Mahdi, E., ElNesr, K., 2015a. Immune stimulation improves endocrine and neural fetal outcomes in a model of maternofetal thyrotoxicosis. Int. Immunopharmacol. 29, 714-721.

[59] Ahmed, R.G., Davis, P.J., Davis, F.B., De Vito, P., Farias, R.N., Luly, P., Pedersen, J.Z., Incerpi, S., 2013b. Nongenomic actions of thyroid hormones: from basic research to clinical applications. An update. Immunology, Endocrine \& Metabolic Agents in Medicinal Chemistry, 13(1), 46-59.

[60] Ahmed, R.G., El-Gareib, A.W. 2014. Lactating PTU exposure: I- Alters thyroid-neural axis in neonatal cerebellum. Eur. J. of Biol. and Medical Sci. Res. 2(1), 1-16.

[61] Ahmed, R.G., El-Gareib, A.W., 2017. Maternal carbamazepine alters fetal neuroendocrinecytokines axis. Toxicology 382, 59-66.

[62] Ahmed, R.G., El-Gareib, A.W., Incerpi, S., 2014. Lactating PTU exposure: II- Alters thyroid-axis and prooxidant-antioxidant balance in neonatal cerebellum. Int. Res. J. of Natural Sciences 2(1), 1-20.

[63] Ahmed, R.G., Incerpi, S., 2013. Gestational doxorubicin alters fetal thyroid-brain axis. Int. J. Devl. Neuroscience 31, 96-104.
[64] Ahmed, R.G., Incerpi, S., Ahmed, F., Gaber, A., 2013a. The developmental and physiological interactions between free radicals and antioxidant: Effect of environmental pollutants. J. of Natural Sci. Res. 3(13), 74-110.

[65] Barden, N., Reul, J., Holsboer, F., 1995. Do antidepressants stabilize mood through actions on the hypothalamic-pituitary-adrenocortical system? Trends in Neurosciences 18, 6-11.

[66] Bauer, M., Baur, H., Berghofer, A., Strohle, A., Hellweg, R., Muller-Oerlinghausen, B., Baumgartner, A., 2002. Effects of supraphysiological thyroxine administration in healthy controls and patients with depressive disorders. Journal of Affective Disorders 68, 285-294.

[67] Baumgartner, A., Graf, K., Kurten, I., Meinhold, H., 1988. The hypothalamicpituitary-thyroid axis in psychiatric patients and healthy subjects: parts 1-4. Psychiatry Res 24, 271-332.

[68] Brouwer, J.P., Appelhof, B.C., Hoogendijk, W.G.J., Huyser, J., Endert, E., Zuketto, C., et al., 2005. Thyroid and adrenal axis in major depression: a controlled study in outpatients. Eur J of Endocrinology 152, 185-191.

[69] Candelotti, E., De Vito, P., Ahmed, R.G., Luly, P., Davis, P.J., Pedersen, J.Z., Lin, H-Y., Incerpi, I., 2015. Thyroid hormones crosstalk with growth factors: Old facts and new hypotheses. Immun., Endoc. \& Metab. Agents in Med. Chem., 15, 71-85.

[70] Chung, H.R., 2014. Adrenal and thyroid function in the fetus and preterm infant.Korean J Pediatr 57(10), 425-433.

[71] Coiro, V., Volpi, R., Marchesi, C., DeFerri, A., Capretti, L., Caffarri, G., Colla, R., Chiodera, P., 1998. Different effects of pyridostigmine on the thyrotropin response to thyrotropinreleasing hormone in endogenous depression and subclinical thyrotoxicosis. Metabolism 47, 50-53.

[72] De Vito, P., Candelotti, E., Ahmed, R.G., Luly, P., Davis, P.J., Incerpi, S., Pedersen, J.Z., 2015. Role of thyroid hormones in insulin resistance and diabetes. Immun., Endoc. \& Metab. Agents in Med. Chem., 15, 86-93.

[73] Dilsaver, S., Greden, J., 1985. Effects of antidepressant withdrawal on the dexamethasone suppression test. Psychiatry Res $14,11-22$.

[74] El-bakry, A.M., El-Ghareeb, A.W., Ahmed, R.G., 2010. Comparative study of the effects of experimentally-induced hypothyroidism and hyperthyroidism in some brain regions in albino rats. Int. J. Dev. Neurosci. 28, 371-389. 
[75] El-Ghareeb, A.A., El-Bakry, A.M., Ahmed, R.G., Gaber, A., 2016. Effects of zinc supplementation in neonatal hypothyroidism and cerebellar distortion induced by maternal carbimazole. Asian Journal of Applied Sciences 4(04), 1030-1040.

[76] Endendijk, J.J., Wijnen, H.A.A., Pop, V.J.M., van Baar, A.L., 2017. Maternal thyroid hormone trajectories during pregnancy and child behavioral problems. Hormones \& Behav. 94, 84-92.

[77] Engum, A., Bjoro, T., Mykletun, A., Dahl, A., 2002. An association between depression anxiety and thyroid function - a clinical fact or an artefact? Acta Psychiatrica Scandinavica 106, 27-34.

[78] Fisher, D.A., 1997. Fetal thyroid function: diagnosis and management of fetal thyroid disorders. Clin Obstet Gynecol 40, 16-31.

[79] Gigena, N., Alamino, V.A., Montesinos, M.M., Nazar, M., Louzada, R.A., Wajner, S.M., Maia, A.L., Masini-Repiso, A.M., Carvalho, D.P., Cremaschi G.A., Pellizas, C.G., 2017. Dissecting thyroid hormone transport and metabolism in dendritic cells. J. Endocrinology 232, 337-350.

[80] Haggerty, J.Jr., Simon, J., Evans, D., Nemeroff, C., 1987. Relationship of serum TSH concentration and antithyroid antibodies to diagnosis and DST response in psychiatric inpatients. American Journal of Psychiatry 144, 1491-1493.

[81] Hillman, N.H., Kallapur, S.G., Jobe, A.H., 2012. Physiology of transition from intrauterine to extrauterine life. Clin Perinatol 39, 769-783.

[82] Holsboer, F., Barden, N., 1996. Antidepressants and hypothalamic-pituitary-adrenocortical regulation. Endocrine Reviews 17, 187-205.

[83] Incerpi, S., Hsieh, M-T., Lin, H-Y., Cheng, GY., De Vito, P., Fiore, A.M., Ahmed, R.G., Salvia, R., Candelotti, E., Leone, S., Luly, P., Pedersen, J.Z., Davis, F.B., Davis, P.J., 2014. Thyroid hormone inhibition in L6 myoblasts of IGF-I-mediated glucose uptake and proliferation: new roles for integrin $\alpha \mathrm{v} \beta 3$. Am. J. Physiol. Cell Physiol. 307, C150-C161.

[84] Ishimoto, H., Jaffe, R.B., 2011. Development and function of the human fetal adrenal cortex: a key component in the feto-placental unit. Endocr Rev 32, 317-355.

[85] Jackson, I., 1998. The thyroid axis and depression. Thyroid 8, 951-956.

[86] Kirkegaard, C., Faber, J., 1998. The role of thyroid hormones in depression. Eur $\mathbf{J}$ of Endocrinology 138, 1-9.

[87] Kirkegaard, C., Korner, A., Faber, J., 1990. Increased production of thyroxine and inappropriately elevated serum thyrotropin in levels in endogenous depression. Biological Psychiatry 27, 472-476.

[88] Kraus, R., Hux, M., Grof, P., 1987. Psychotropic drug withdrawal and the dexamethasone suppression test. American Journal of Psychiatry 144, 82-85.

[89] Kronenberg, H.M., Melmed, S., Polonsky, K.S., Larsen, P.R., 2008. Williams textbook of endocrinology. 11th ed. Philadelphia: Saunders.

[90] La Gamma, E.F., van Wassenaer, A.G., Ares, S., Golombek, S.G., Kok, J.H., Quero, J., et al., 2009. Phase 1 trial of 4 thyroid hormone regimens for transient hypothyroxinemia in neonates of $<28$ weeks' gestation. Pediatrics 124, e258-268.

[91] McCowen, K., Garber, J., Spark, R., 1997. Elevated serum thyrotropin in thyroxine-treated patients with hypothyroidism given sertraline. New England J of Medicine 337, 1010-1011.

[92] Mesiano, S., Jaffe, R.B., 1997. Developmental and functional biology of the primate fetal adrenal cortex. Endocr Rev 18, 378-403.

[93] Michelson, D., Stratakis, C., Hill, L., Reynolds, J., Galliven, E., Chrousos, G., Gold, P., 1996. Bone mineral density in women with depression. New England J of Medicine 335, 1176-1181.

[94] Ng, P.C., 2000. The fetal and neonatal hypothalamic-pituitary-adrenal axis. Arch Dis Child Fetal Neonatal Ed 82, F250-254.

[95] Oldehinkel, A., van, dB., Flentge, F., Bouhuys, A., ter Horst, G., Ormel, J., 2001. Urinary free cortisol excretion in elderly persons with minor and major depression. Psychiatry Res. 104, 3947.

[96] Rubin, R., Poland, R., Lesser, I., Winston, R., Blodgett, A., 1987. Neuroendocrine aspects of primary endogenous depression. I. Cortisol secretory dynamics in patients and matched controls. Archives of General Psychiatry 44, 328-336.

[97] Schule, C., Baghai, T., Rackwitz, C., Laakmann, G., 2003. Influence of mirtazapine on urinary free cortisol excretion in depressed patients. Psychiatry Research 120, 257-264.

[98] Sullivan, P., Wilson, D., Mulder, R., Joyce, P., 1997. The hypothalamic-pituitary-thyroid axis in major depression. Acta Psychiatrica Scandinavica 95, 370-378.

[99] Van Herck, S.L.J., Geysens, S., Bald, E., Chwatko, G., Delezie, E., Dianati, E., Ahmed, R.G., Darras, V.M., 2013. Maternal transfer of methimazole and effects on thyroid hormone availability in embryonic tissues. Endocrinol. 218, 105-115. 
[100]Watterberg, K.L., 2004. Adrenocortical function and dysfunction in the fetus and neonate. Semin Neonatol 9, 13-21.
[101]Young, E., Carlson, N., Brown, M., 2001. Twenty-four-hour ACTH and cortisol pulsatility in depressed women. Neuro psychopharmacology 25, 267-276.

Citation: Ahmed R.G. Maternal Thyroid-Adrenal Dysfunction and Fetal-Neonatal Depression. ARC Journal of Animal and Veterinary Sciences. 2018; 4(2):49-54. doi: dx.doi.org/ 10.20431/2455-2518.0402007.

Copyright: () 2018 Authors. This is an open-access article distributed under the terms of the Creative Commons Attribution License, which permits unrestricted use, distribution, and reproduction in any medium, provided the original author and source are credited. 